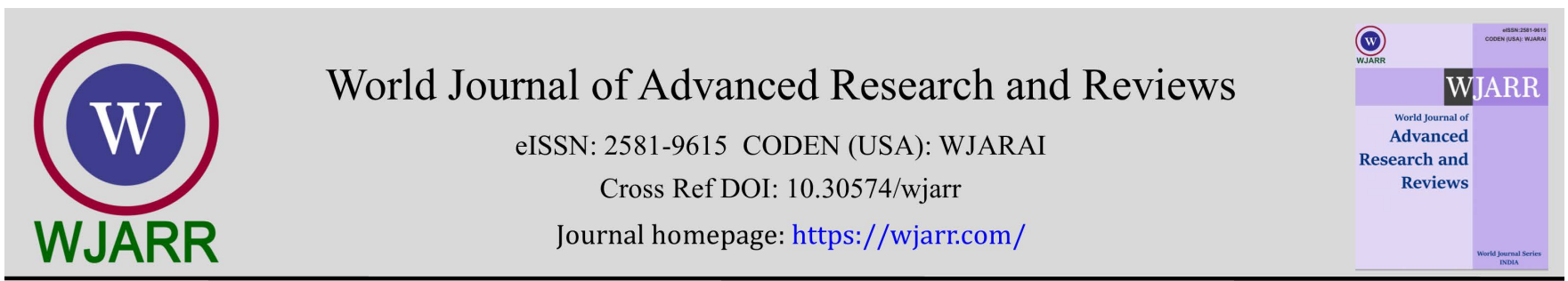

(RESEARCH ARTiClE)

Check for updates

\title{
An analysis of the effect of procurement practices on public institutions: an examination of Metropolitan, Municipal and District Assemblies (mmdas) in the Ashanti region of Ghana
}

\author{
Moisob Adamu ${ }^{1,}{ }^{*}$, Kelvin Gyamfi ${ }^{2}$ and Graham Billa ${ }^{3}$ \\ ${ }^{1}$ Ahafo Ano South-West District Assembly, Box 9, Mankranso-Kumasi. \\ ${ }^{2}$ Local Government Service of Ghana, Box MB 396, Ministries-Accra. \\ ${ }^{3}$ C.K Tedam University of Technology \& Applied Sciences, Navrongo-Upper East.
}

World Journal of Advanced Research and Reviews, 2021, 12(03), 083-093

Publication history: Received on 25 September 2021; revised on 25 November 2021; accepted on 27 November 2021

Article DOI: https://doi.org/10.30574/wjarr.2021.12.3.0490

\begin{abstract}
Governments in both affluent and developing countries employ procurement strategies to decrease costs, resulting in large cash outflows that have a substantial influence on their economy. However, especially in the public sector, public procurement practices are usually disregarded in terms of their impact on an organization's success. As a result, utilizing Metropolitan, Municipal, and Distract Assemblies (MMDAs) in Ghana's Ashanti Region as case study institutions, it is unavoidable to investigate public sector procurement practices and their impact on organizational performance. The survey study design was used to map out the data collection process. A purposively sampled cohort of 113 people was used to administer the questionnaire. Using the Probit Regression Model, the study claims that procurement practices such as planning, sourcing, and contract management have a substantial positive link with organizational success. Given the interdependence of all dimensions of procurement practices, procurement practitioners are urged to give each factor proportionate attention to improve organizational performance.
\end{abstract}

Keywords: MMDAs; Procurement; Practices; Organizational Performance

\section{Introduction}

Public procurement is seen as a profession that is critical to the effective management of public resources all over the world. As a result, most countries have realized the importance of procurement as a vulnerable sector to mismanagement and corruption [29] Public procurement, particularly at the local government level, has been identified as a key area where corruption is believed to be widespread [28] Following these events, Ghana's procurement practices have been reformed with the goal of minimizing corruption and ensuring value for money and efficiency in procurement processes. Procurement practices are defined by [16] as a series of activities carried out by an organization to achieve effective supply chain management. To support this claim, it is critical that public sector institutions adhere to the fundamentals of basic procurement processes, of which contract management is a key component. Contract management ideals include ensuring that all contract parties fully meet their respective commitments as efficiently and effectively as possible through the delivery of essential operational outputs to get value for money. What [1] has talked about (opportunism in Agency Theory) will be a profitable idea to hide beneath if regarded indifferently. [1] claims that opportunism usually takes more nuanced forms, involving actions and inactions taken ex-ante (before the contract is signed), in tract (during the fulfillment of contract's obligations), and ex-post (after the contract has been signed) (after the contract is signed).

\footnotetext{
* Corresponding author: Moisob Adamu

Ahafo Ano South-West District Assembly, Box 9, Mankranso-Kumasi. 
All of these efforts are directed toward the organization's fulfillment of certain objectives. The most important factor is organizational performance, which is the difference between an institution's actual output and its intended output [21] Cost reduction, quality of goods or services delivered, productivity, lead time, and other metrics can all be used to assess an organization's performance [2] According to [20] organizational performance can also be measured based on the efficacy and efficiency of the institution. According to [25] the performance of public sector organizations such as the Metropolitan, Municipal, and District Assemblies (MMDAs) should be judged on financial factors such as sales growth, profit, and return on investment, business performance, and organizational effectiveness. This aligns with [13] definition of organizational success as three distinct areas of business outcomes: financial performance, product market performance, and shareholder return. Certainly, there is a significant link between procurement procedures and organizational performance, as one step frequently leads to the other, so when one falls, the other is impacted.

\subsection{The Problem Statement}

Local government governance and procurement processes are one area of the public sector that requires scrutiny. In truth, rushed contract awards without proper planning, contract mismanagement, and intentional wrongful outsourcing of contracts to cronies and families to obtain "kick-backs" are all examples of contract mismanagement. Most economies lose millions of dollars due to poor contract management [1] [14] put it succinctly that the desire to implement one's own personal interests (as captured under agency theory) such as lying, stealing, and cheating are factored in the concept of "opportunism" under the Principal-Agency engagement. Contract management is considered subject to corruption and inefficiency in Ghana, according to [7], and has caused the public to lose the trust that existed previously. That is why [32] stipulates that adequate procurement methods be used to ensure that parties adhere to performance agreements.

Procurement violations have grown prevalent at the MMDAs, according to a seen report by Ghana's Auditor-General (A$\mathrm{G}$ ), and management has failed to penalize wrongdoers. Procurement irregularities cost the government GH187.43 million between 2014 and 2018. [40]; [39] .Even though the Public Procurement Act 663 (as amended) was passed, as a result of collaboration between personnel and suppliers, incomplete orders that do not satisfy needed standards are accepted with receiving slips stating that a full order with the appropriate requirements was delivered.

Defects and weaknesses in the internal controls of the various District Assemblies were revealed in the same [39], as a result of ineffective supervision, weak expenditure controls, and non-enforcement of relevant laws, all of which contributed to recurring irregularities, according to the [40] Furthermore, the reports claim that procurement, store, and contractual irregularities resulted in compliance violations, such as the use of non-competitive procurement methods such as single source without prior approval from the Public Procurement Authority (PPA), unaccounted for fuel and stores, payments for maintenance work without certification, and contracts not executed to specification [41] Following the foregoing discoveries and counter-arguments, the current study aims to answer the following questions: How important is procurement planning to the success of an organization? What impact does sourcing have on an organization's performance? How important is contract management to the success of an organization?

\section{Literature}

In the framework of the firm's theory of agency, a greater understanding of the impact of procurement methods on organizational performance can be gained [26]. Jensen and [37] are at the heart of the agency hypothesis. The hypothesis proposes that the owners and managers of a company's goals are incompatible. While the latter is in charge of the company's day-to-day operations, ostensibly for self-aggrandizement at the expense of the former (owners). Similarly, the decisions and behaviors of MMDA heads are disproportionately geared toward self-achievement. As a result, the agency theory has given rise to a new perspective in public procurement research that emphasizes the subject matter's mutability and relativity [1] .As a concept, cognition usually presupposes formalized contracts for public services, such as public-private partnerships and service delivery agreements. In an open sense, the national government delegated contracting for services to our local governments (MMDAs) through the procurement of deliverables. However, due to the bounded rationality of the parties in this case (Central Government-MMDAs) and the complexities of situations that arise from contract formation and execution, the agent's (MMDAs) decisions and actions that maximize the Principal's (Central Government) welfare are frequently divergent and conflicting [31], which ultimately makes the aging process more difficult. In this instance, central governments may do all possible to reduce costs and get value for money, but MMDAs' interests usually prevail at the end of the day due to disparities in interest in contract formation and the benefits therefrom. As a result, the intended link between procurement procedures and agency theory is hampered by the parties' competing agendas. 


\subsection{Empirical Review}

There is existing literature and research on the effects of procurement practices on a variety of other factors and their impact on performance, but most of these studies were conducted in private corporations and developed economies, with few or no such studies conducted in public or government institutions, particularly in the developing economies of most African countries. Organizational performance is influenced by procurement practices, according to studies such as ([35]; [6]; [30];, [23], and [24], claim that there is a favorable relationship between contract management and company performance in their study. [8] found contract management to be positively connected with Kenyan telecommunication enterprises. [9] investigated contract management methods and state corporation operational performance in Kenya. Her findings demonstrate that state businesses have an effective contract management culture, which is favorably associated with organizational success. [11] Discovered a substantial association between quality standards and institutional performance when researching the effect of procurement planning on institutional performance in Mombasa, Kenya. Still on procurement planning, [3] and [27] found a strong link between procurement need identification measures and procurement performance in terms of timely delivery and cost savings. [15] investigated the problem of sourcing in Rwanda in order to identify the impact of outsourcing on organizational performance. In two cases, the study found that, while outsourcing had a modest positive relationship with cost efficiency, outsourcing activities had a weak and moderate positive relationship with productivity and firm performance in terms of profitability, respectively.

\subsection{Conceptual Framework of the research.}

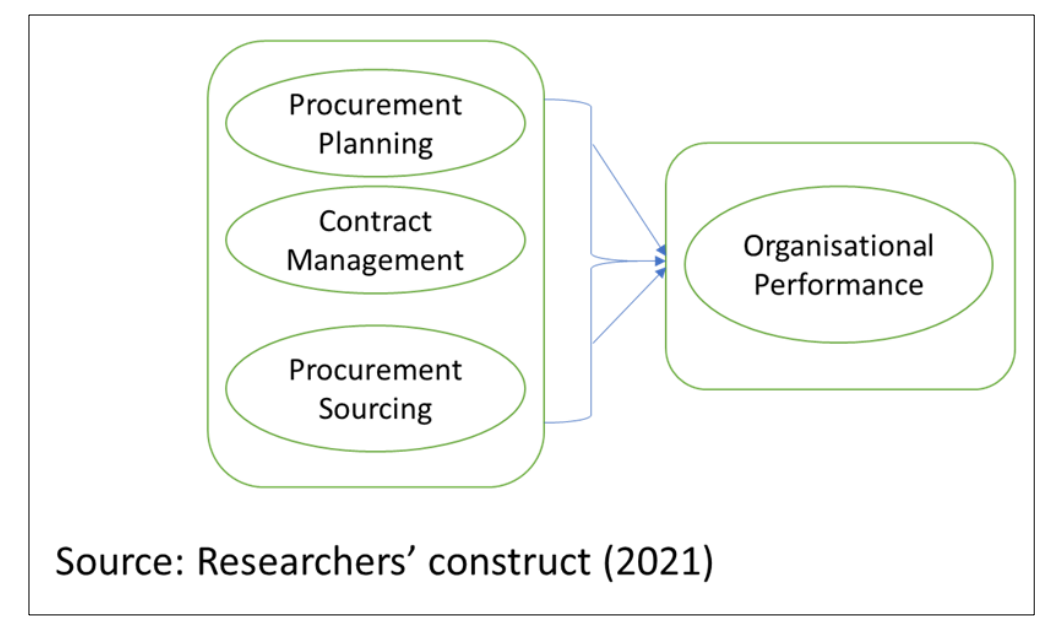

Figure 1 Conceptual Framework

\section{The research methodology}

The goal of the study was to look into the impact of procurement methods on organizational performance in a few MMDAs in Ghana's Ashanti Region. To collect data and analyze it into a usable form for inferences, a cross-sectional survey design using a quantitative method was used.

\subsection{Population of the study}

All MMDAs in the Ashanti Region were included in the target population, and a sample was chosen using the availability sampling technique. Because of the nature of the concepts under inquiry, it was necessary to examine a population that could supply researchers with all of the information they needed to meet the study's aims. As a result, the Ashanti Region's Metropolitan, Municipal, and District Assemblies (MMDAs) were targeted.

\subsection{Sampling procedure and sample size}

Researchers used an approach called "purposive sampling." This technique was chosen objectively based on previous experiences, locations, and their ability to provide the data needed to answer the research questions [33] , and [19]. [29] developed a formula for calculating sample size in this investigation. The number of people in the sample frame was 253. The initial visit to the Metropolitan, Municipal, and District Assemblies resulted in this (MMDAs). A confidence level of $95 \%$ was used to achieve excellent accuracy and a strong representation of the target population. Using Miller and Brewer's (2003) mathematical formulae: 
$\mathrm{n}=\frac{N}{1+N(\alpha)^{2}}$

Where:

$\mathrm{N}=$ the sample frame,

$\mathrm{n}=$ is the sample size and

$\alpha=$ is the margin of error (which is 0.05 )

$\mathrm{n}=\frac{253}{1+253(0.05)^{2}}$

$\mathrm{n}=\frac{253}{1+253(0.0025)}$

$\mathrm{n}=154.977$ ( 3 decimals places $)$

Since human population is not fractional or decimal, the sample size was agreed at an approximated figure of 155 participants.

\subsection{Model specification}

The Probit model was used

$\mathrm{ORG}-\mathrm{P}=B_{0}+B_{1}(\mathrm{PP})+B_{2}(\mathrm{CM})+B_{3}(\mathrm{PS})+\varepsilon$

Where:

ORG-P = Organisational Performance

$\mathbf{P P}=$ Procurement Planning

$\mathbf{C M}=$ Contract Management

PS = Procurement Sourcing

Where:

ORG-P stands for "Organizational Performance."

PP stands for Procurement Planning.

CM stands for Contract Management.

PS stands for Procurement Sourcing.

\subsection{Study variables}

For the analysis, the study used four variables. One of these variables (organizational performance [ORG-P]) was utilized as the outcome variable, while the other three (procurement planning, contract management, and procurement sourcing) were used to regress on the dependent variable.

\subsection{Data Collection Method and Analysis}

A questionnaire was used to obtain primary data. For the necessary data, a Likert scale questionnaire was designed and administered to selected respondents. With the use of Microsoft Excel and Eviews 9.0, this study analyzed the data using descriptive and inferential (regression) statistics. 


\section{Results and discussion}

\subsection{Data response}

A total questionnaire of 155 was issued to the various respondents; the researcher was able to retrieve 113 questionnaires due to the lockdown sanctions by the government. In view of that, 113 questionnaires were obtained and subsequently used for the analysis which in practice constituted about $91.8 \%$ of the data accrued. This in effect makes the research reliable, and viable.

Table 1 Educational Response

\begin{tabular}{|l|l|c|c|c|}
\hline \multirow{3}{*}{ Valid } & Frequency & Valid Percent & Cumulative Percent \\
\cline { 2 - 5 } & Secondary school or related certificate & 3 & 2.6 & 2.6 \\
\cline { 2 - 5 } & Diploma/HND & 16 & 14.2 & 16.8 \\
\cline { 2 - 5 } & First degree & 90 & 79.6 & 96.4 \\
\cline { 2 - 5 } & Second degree & 4 & 3.5 & 100.0 \\
\cline { 2 - 5 } & Total & 113 & 100.0 & \\
\hline
\end{tabular}

Source: Researchers' construct, 2021

Educational background of respondents is also another vital variable that needs to be shown in almost every study in order to place some value on the ability of the respondents to read and understand the questions been put before them especially when the questionnaire is to be administered by the respondents themselves without any assistance from the researcher. For this study the educational level of the respondents is shown in the table above. From the Table 4.3, $3(2.6 \%)$ of the respondents are with SSCE/Related certificate, 16 (14.2\%) are with HND/ Diploma, 90 (79.6\%) are with First Degree, $4(3.5 \%)$ are with Second degree. With these results, it can be seen that the educational level of the respondents was pretty high and for this it can be assumed that they really understood the context of the questions in the questionnaire.

Table 2 Managerial Level Response

\begin{tabular}{|l|l|l|l|l|}
\hline \multirow{3}{*}{ Valid } & & Frequency & Valid Percent & Cumulative Percent \\
\cline { 2 - 5 } & Supervisor & 41 & 36.3 & 36.3 \\
\cline { 2 - 5 } & Middle manager & 54 & 47.7 & 84.0 \\
\cline { 2 - 5 } & Top manager & 18 & 15.9 & 100.0 \\
\cline { 2 - 5 } & Total Source: Researchers' construct, 2021 \\
\hline
\end{tabular}

Moreover, the various positions the respondents hold in the Metropolitan, Municipal, and District Assemblies (MMDAs) were also asked from them, and their results are shown in the table above are highlighted below. Supervisors are 41 (36.3\%), Middle Managers are 54 (47.7\%), and Top Managersare18 (15.9\%). This indicates a high percentage involvement of Middle Managers in the study as compared to the other positions that the respondents hold.

Table 3 Firm-Industry Description

\begin{tabular}{|l|l|c|c|c|}
\hline \multirow{3}{*}{ Valid } & Service & Frequency & Valid Percent & Cumulative Percent \\
\cline { 2 - 5 } & Mining/Extraction & 100 & 88.5 & 88.5 \\
\cline { 2 - 5 } & Agricultural/Agribusiness & 4 & 3.5 & 92.0 \\
\cline { 2 - 5 } & Manufacturing & 2 & .8 & 92.8 \\
\cline { 2 - 5 } & Other & 6 & 5.3 & 94.5 \\
\cline { 2 - 5 } & Total & 113 & 100.0 & 100.0 \\
\hline
\end{tabular}


From table 3, the firm-industry descriptions were considered. The various fields were considered too. From the table, the researcher was looking for diversity and the way people understand procurement practices. In categorization, 100 (88.5\%) represent people from the service sector, 4 (3.5\%) represent the mining /extraction, 1 (0.8) represent the agricultural/agribusiness, 2 (1.7\%) manufacturing, and 6 (5.3\%) other. from the table shows clearly that service amassed a higher proportion of the total responses.

Table 4 Head of Procurement

\begin{tabular}{|l|l|c|c|c|}
\hline & & Frequency & Valid Percent & Cumulative Percent \\
\hline \multirow{3}{*}{ Valid } & Male & 73 & 64.60 & 64.60 \\
\cline { 2 - 5 } & Female & 40 & 35.39 & 100.0 \\
\cline { 2 - 5 } & Total & 113 & 100.0 & \\
\hline
\end{tabular}

From table 4 shows the head of procurement categorized into males and females. The table shows a clear proportion of the respondents. $73(64.60 \%)$ represent males whiles 40 (35.39\%) represent females. The table above, shows male dominance so far as Head of procurement in the Metropolitan, Municipal and District Assemblies (MMDAs) are concern.

\subsection{Descriptive Statistics of the Variables in the Model}

In this section, the construct item measurements of the various variables used are been presented descriptively [12]. The items include sourcing, procurement planning, contract management and organizational performance. The presentations are shown in the tables below. The descriptive include the number of responses, minimum and maximum value, the mean responses, standard deviation. The mean shows the average weight of the responses. A greater mean value is an indication that the respondents on average assigned huge values to such items, which notifies their high level of agreement to that particular construct statement. However, the standard deviation shows how spread the data is from the mean. It is the deviation from the mean, the smaller the value, the better. The benchmark mean for the study is 3.5 .

Table 5 Sourcing Descriptive Statistics

\begin{tabular}{|l|l|c|c|c|c|}
\hline & $\mathbf{N}$ & Minimum & Maximum & Mean & Std. Deviation \\
\hline Identifying important sources of supply & 113 & 2.00 & 7.00 & 4.9823 & 1.36919 \\
\hline Developing comprehensive tender documents & 113 & 2.00 & 7.00 & 4.3274 & 1.52035 \\
\hline Inviting potentially relevant suppliers & 113 & 1.00 & 7.00 & 4.9469 & 1.61378 \\
\hline Evaluating and selecting suppliers & 113 & 1.00 & 7.00 & 3.9823 & 1.73196 \\
\hline Developing comprehensive contract documents & 113 & 1.00 & 7.00 & 4.3982 & 1.53844 \\
\hline Negotiating contract term for value & 113 & 2.00 & 7.00 & 4.4248 & 1.32830 \\
\hline Awarding contract timely & 113 & 1.00 & 7.00 & 4.0088 & 1.35288 \\
\hline Valid N (list wise) & 113 & & & & \\
\hline
\end{tabular}

Source: Researchers' Construct, 2021

Table 5 above shows the extent to which the items for sourcing presented above are adopted by the Metropolitan, Municipal, and District Assemblies (MMDAs). This result shows the current level at which sourcing is adopted by the Metropolitan, Municipal, and District Assemblies (MMDAs) in Ghana. On a scale of $1-7$, the respondents in the Metropolitan, Municipal, and District Assemblies (MMDAs) were asked to indicate the extent to which they agree to Sourcing as a procurement practice. The scale ranged from 1= not effective at all, 2= not effective, 3= completely not effective, $4=$ somewhat not effective, $5=$ effective, $6=$ somewhat effective, $7=$ completely effective. The mean score presented by the descriptive statistics for each item was matched against the Likert scale to assess sourcing in the Metropolitan, Municipal, and District Assemblies (MMDAs). 
Generally, sourcing in the Metropolitan, Municipal, and District Assemblies (MMDAs) is optimally good. All the various measured items are above the mean score of 3.5. This shows that there is a positive agreement to the fact that sourcing as a procurement practice is acknowledged in the Metropolitan, Municipal, and District Assemblies (MMDAs). [38] as indicated by the United Nation Office of Project Services [35] sourcing for potential suppliers can be collected and collated from external sources and internal sources and these are: United Nation Global Marketplace (UNGM), Commercial/Specialized Journals and Magazines such as Lancet, The Country and Regional Global Compact network, trade directories, exhibitions, colleagues, publications, catalogs library, suppliers recorded performance, suppliers' reputation, etc.

Table 6 Procurement Planning Descriptive Statistics

\begin{tabular}{|l|l|c|c|c|c|}
\hline & $\mathbf{N}$ & Minimum & Maximum & Mean & Std. Deviation \\
\hline Identifying relevant procurement needs & 113 & 1.00 & 7.00 & 4.9646 & 1.54069 \\
\hline $\begin{array}{l}\text { Translating procurement into contract } \\
\text { specifications }\end{array}$ & 113 & 1.00 & 7.00 & 5.1416 & 1.69488 \\
\hline $\begin{array}{l}\text { Developing procurement plan for specific } \\
\text { procurement items }\end{array}$ & 113 & 1.00 & 7.00 & 4.8761 & 1.65364 \\
\hline $\begin{array}{l}\text { Procurement based on needs identification } \\
\text { initiated by user departments }\end{array}$ & 113 & 1.00 & 7.00 & 4.9469 & 1.67886 \\
\hline $\begin{array}{l}\text { Developing budgets for various procurement } \\
\text { needs }\end{array}$ & 113 & 1.00 & 7.00 & 4.6814 & 1.65435 \\
\hline $\begin{array}{l}\text { Approval of procurement plan by the } \\
\text { appropriate approving authorities } 113\end{array}$ & 1.00 & 7.00 & 4.8496 & 1.75368 \\
\hline \begin{tabular}{l} 
Valid N (list wise) \\
\hline
\end{tabular} & 113 & & & \\
\hline
\end{tabular}

Table 6 above shows the extent to which the items for procurement planning presented above are adopted by the Metropolitan, Municipal, and District Assemblies (MMDAs). This result shows the current level at which procurement planning is adopted by the Metropolitan, Municipal, and District Assemblies (MMDAs). On a scale of 1 - 7, the respondents in the Metropolitan, Municipal, and District Assemblies (MMDAs) were asked to indicate the extent to which they agree to procurement planning as a procurement practice. The scale ranged from $1=$ not effective at all, $2=$ not effective, $3=$ completely not effective, $4=$ somewhat not effective, $5=$ effective, $6=$ somewhat effective, $7=$ completely effective. The mean score presented by the descriptive statistics for each item was matched against the Likert scale to assess procurement planning in the Metropolitan, Municipal, and District Assemblies (MMDAs). Generally, procurement planning in the Metropolitan, Municipal, and District Assemblies (MMDAs) is practically good. All the various measured items are above the mean score of 3.5. This shows that there is positive agreement to the fact that procurement planning as procurement practice is championed in the Metropolitan, Municipal, and District Assemblies (MMDAs). The planning function encompasses defining an organizations goal, establishing an overall strategy for achieving those goals, and developing a comprehensive hierarchy of plans to integrate and coordinate the activities as stated by (United Nation Office of Project Services [35]

Table 7 Contract Management Descriptive Statistics

\begin{tabular}{|l|l|c|c|c|c|}
\hline & N & Minimum & Maximum & Mean & Std. Deviation \\
\hline $\begin{array}{l}\text { Managing relationships with key suppliers to } \\
\text { ensure compliance }\end{array}$ & 113 & 1.00 & 7.00 & 4.9292 & 1.92129 \\
\hline $\begin{array}{l}\text { Expediting/Monitoring suppliers' delivery } \\
\text { schedules and obligations }\end{array}$ & 113 & 1.00 & 7.00 & 4.4513 & 1.71647 \\
\hline $\begin{array}{l}\text { Reviewing/modifying contracts to meet } \\
\text { changing needs }\end{array}$ & 113 & 1.00 & 7.00 & 4.6814 & 1.76911 \\
\hline $\begin{array}{l}\text { Processing payment to suppliers } \\
\text { Salid N (list wise) }\end{array}$ & 113 & 2.00 & 7.00 & 5.1593 & 1.86876 \\
\hline
\end{tabular}


Table 7 above shows the extent to which the items for contract management presented above are adopted by the Metropolitan, Municipal, and District Assemblies (MMDAs). This result shows the current level at which contract management is adopted by the Metropolitan, Municipal, and District Assemblies (MMDAs). On a scale of 1 - 7, the respondents in the Metropolitan, Municipal, and District Assemblies (MMDAs) were asked to indicate the extent to which they agree to contract management as a procurement practice.

The scale ranged from $1=$ not effective at all, $2=$ not effective, $3=$ completely not effective, $4=$ somewhat not effective, $5=$ effective, $6=$ somewhat effective, $7=$ completely effective. The mean score presented by the descriptive statistics for each item was matched against the Likert scale to assess contract management in the Metropolitan, Municipal, and District Assemblies (MMDAs). All the various measured items are above the mean score of 3.5 and show that there is positive agreement to the fact that contract management as procurement practice is looked at very cautiously in the Metropolitan, Municipal, and District Assemblies (MMDAs). [34] argues that suppliers get motivated to do business with firms that have effective contract units where activities are straightforward, needs and deadlines met, and costs are well managed; hence enhanced performance.

Table 8 Organizational Performance Descriptive Statistics

\begin{tabular}{|l|c|c|c|c|c|}
\hline & $\mathbf{N}$ & Minimum & Maximum & Mean & Std. Deviation \\
\hline $\begin{array}{l}\text { Managing relationships with key suppliers to } \\
\text { ensure compliance }\end{array}$ & 113 & 1.00 & 7.00 & 4.9292 & 1.92129 \\
\hline $\begin{array}{l}\text { Expediting/Monitoring suppliers' delivery } \\
\text { schedules and obligations }\end{array}$ & 113 & 1.00 & 7.00 & 4.4513 & 1.71647 \\
\hline $\begin{array}{l}\text { Reviewing/modifying contracts to meet } \\
\text { changing needs }\end{array}$ & 113 & 1.00 & 7.00 & 4.6814 & 1.76911 \\
\hline $\begin{array}{l}\text { Processing payment to suppliers } \\
\text { Valid N (list wise) }\end{array}$ & 113 & 2.00 & 7.00 & 5.1593 & 1.86876 \\
\hline
\end{tabular}

Table 8 above shows the extent to which the items for an organizational performance presented above are adopted by the Metropolitan, Municipal, and District Assemblies (MMDAs). This result shows the current level of organizational performance in the Metropolitan, Municipal, and District Assemblies (MMDAs). On a scale of $1-7$, the respondents in the Metropolitan, Municipal, and District Assemblies (MMDAs) were asked to indicate the extent to which they agree to the items presented under organizational performance. The scale ranged from $1=$ not effective at all, $2=$ and $7=$ completely effective. The mean score presented by the descriptive statistics for each item was matched against the Likert scale to assess the level of organizational performance in the Metropolitan, Municipal, and District Assemblies (MMDAs). Generally, organizational performance in the Metropolitan, Municipal, and District Assemblies (MMDAs) is on the rise and good. All the various measured items are above the mean score of 3.5. This shows that there is positive agreement to the fact that organizational performance is encouraging in the Metropolitan, Municipal, and District Assemblies (MMDAs).

\subsection{Reliability of the Study}

Reliability analysis is applied to determine the internal consistency of the variables in the study. Internal consistency of the items was measured using the Cronbach's Alpha coefficient. The items were considered to represent an acceptable level of internal consistency if the Cronbach's alpha value within $0.5-0.7$ and good level if the Cronbach's Alpha value is more than $0.7[10]$

Table 9 Reliability Test

\begin{tabular}{|l|c|c|}
\hline Variable & Cronbach alpha & Number of items \\
\hline Sourcing & 0.712 & 6 \\
\hline Procurement planning & 0.730 & 6 \\
\hline Contract management & 0.749 & 4 \\
\hline Organizational performance & 0.712 & 5 \\
\hline \multicolumn{2}{|c|}{ Source: Researchers' Own Construct, 2021 } \\
\hline
\end{tabular}


The table 9 above, the Cronbach's Alpha of the various construct are all above the benchmark of 0.7 . This reinforces the internal consistency of the study data and thus the` reliability of the data measurement.

\section{Summary of Findings}

\subsection{Effects of Procurement Planning on Organizational Performance}

The results of Pearson correlation tests conducted on procurement planning and organizational performance show that there was a positive correlation between procurement planning and organizational performance. The result of the regression analysed suggests that there is a positive correlation between procurement planning and organizational performance. It was ascertained that procurement planning accounts for $2.1 \%$ of the variation in organizational performance in Metropolitan, Municipal, and District Assemblies (MMDAs).

\subsection{Effects of sourcing on Organizational Performance}

The results of Pearson correlation test conducted on sourcing and organizational performance shows that there is a correlation between sourcing and organizational performance. The result of the regression analysed suggests that there is a positive correlation between sourcing and organizational performance. It is ascertained that sourcing can account for $4.7 \%$ of the variation in organizational performance in Metropolitan, Municipal, and District Assemblies (MMDAs). The managerial implication is that the management body should devise means that will ensure that actors within the Metropolitan, Municipal, and District Assemblies (MMDAs) procure from a potential source that will help Metropolitan, Municipal, and District Assemblies (MMDAs) to have value for money.

\subsection{Impact of Contract Management on Organizational Performance}

The result of the regression analyzed suggests a positive relationship between contract management and organizational performance. It is established that contract management accounts for $1.7 \%$ of the variation in organizational performance in Metropolitan, Municipal, and District Assemblies (MMDAs).

\section{Conclusion}

Based on the findings, the researchers concluded that procurement planning, procurement sourcing, contract management have a positive impact on an organization's performance. Also, research indicated that the three independent variables thus sourcing, procurement planning, and contract management indicate a positive relationship with the dependent variable organizational performance.

\section{Compliance with ethical standards}

\section{Acknowledgments}

Several faculties and officials were consulted throughout this research. First and foremost, we want to express our thanks to the Business School lecturers at the Ghana Institute of Management and Public Administration (GIMPA) for their unwavering support. Mostly, Professor Samuel Famiyeh (Senior Lecturer), Professor J. Effah of Legon, and all those who contributed directly to this study.

\section{Disclosure of conflict of interest}

There are no conflicts of interest to be disclosed by any of the Authors.

\section{References}

[1] A Chrisidu-Budnik.The agency theory bapproach to the public procurement system - Wroclaw Review of Law wrlae.prawo.uni.wroc. 2017.

[2] A Gunasekaran, C Patel, \& RE McGaughey. A framework for supply chain performance - journal of production Elsevier. 2004.

[3] AS Salim, S Kitheka. Effect of procurement planning on procurement performance of state corporations in Mombasa county, Kenya- ir.tum.ac.ke. 2019.

[4] Audit commission. Annual report and accounts. 2010; 5-96. 
[5] Barnett C, Barr J, Angela C, Duff B. and Hext, S. "Measuring the Impact and Value for Money of Governance and Conflict Programmes". 2010.

[6] BC Basheka. Procurement planning and local governance in Uganda: A factor analysis approach- International journal of procurement - inderscienceonline.com. 2009.

[7] C Ameyaw, S Mensah, \& E Osei-Tutu. Public procurement in Ghana: the implementation challenges to the public procurement Law. 2012; 2003 (Act663).

[8] International Journal of supply chain management - ijcscm.com.

[9] C Cherotich. Evaluating the effects of total reward on job satisfaction among bank employees in Nakuru Municipality, Kenya - thesisbank.jhia.ac.ke. 2012.

[10] C Hulin, Rick Netemeyer, R Cudeck. Can a reliabilty cooefficeint be too high? - Journal of Consumer Psychology JSTOR. 2001.

[11] CJ Onyango. Effect of planning on institutional performance: A case study of Mobmbasa Law court. - International Journal of Science and Research, Citeseer. 2012.

[12] Creswell J. Qualitative inquiry and research design. Thousand Oaks, CA: Sage. 2009.

[13] CS Katsikeas, NA Morgan, LC Leonidou. Assessing performance outcomes in Marketing - journals.sagepub.com. 2016.

[14] C Talbot. Theories of performance: Organizational improvement in the public domain - books.google.com. 2010.

[15] C Uwamahoro Kayumba. Effect of outsourcing on organizational performance in Rwanda - diva-portal.org. 2019.

[16] DK Makabira, E Waiganjo. Role of procurement practices on the performance of coporate organizations in enya: Acase study of Kenya National police service - International Journal of Academic Research. 2014.

[17] Evenett S, Hoekman B. International cooperation and the reform of public procurement policies. 2005.

[18] Ghana Public Procurement Act. (Act 663). Republic of Ghana. Accra Ghana Publishing Corporation. 2003.

[19] Ho Municipal Assembly. Current staff strength of the municipal assembly. Ho Volta Region. 2014.

[20] JK Nkuah, JP Tanyeh, J Ashante. The relationship between financial control systems and public sector efficiency in Ghana. - International Journal of Advanced research. 2013.

[21] JL Perry, LW Porter. Factors affecting the context for motivation in public organization - Academy of management review, - journals.aom.org. 1982.

[22] Kothari CR. Research Methodology, Methods and Techniques, New Age International Publications, New Delhi. 2008.

[23] Lyson CK. Purchasing, 3rdEdition, London; Pitman Publications. 1993.

[24] Lysons K, Farrington B. Purchasing and Supply Chain Management. Pearson Education, 7th Edition, Prentice Hall, England. 2006; 30 - 81, 157 - 180, 243 - 263, 398 - 427.

[25] Leiyan AP. Procurement practices and organizational performance: a case study of the University of Nairobi. 41.204.161.209

[26] M Adusei. The impact of bank size and funding risk on bank stability-Cogent Economics \& Finance- Taylor \& Francis. 2015.

[27] McDonald C. Christian Aid. Buying Aid Power, Governance and Public Procurement, Accra Ghana. 2008.

[28] National Public Procurement Integrity Baseline Survey, 2010.

[29] OECD DAC. Handbook on Security Sector Reform (SSR); supporting security and justice. 2007.

[30] Pallant J. SPSS Survival Manual: A Step by Step Guide to Data Analysis. 2001; 1-145.

[31] PR Schapper, JNV Malta, DL Gilbert. An analytical framework for the management and reform of public procurement- Journal of public procurement, emerald.com. 2012.

[32] P Wright, A Mukheriji, MJ Kroll. A reexamination of agency theory Assumptions: extensions and extrapolations The Journal of Socio-Economics - Elsevier. 2001. 
[33] RG Cooper. Perspective: the stage gate idea to launch process -update- Journal of product innovation management, - Wiley Online Library. 2008.

[34] Saunders M, Levin P, Thornhill A. Research Methods for Business Students, Fifth Edition, Prentice-Hall, London. 2007.

[35] S Lesere. Effects of contract management practices on supply chain performance on manufacturing firms in Nairobi County -Kenya, Journal of International Business, Innovation and strategic management - jibism.org. 2018.

[36] United Nation Office for Project Services UNOPS. - Public Procurement Manual, Revision. 2019; 6(1).

[37] Westring G. "Ghana Public Procurement Reform. An Audit Report prepared for World Bank", Stockholm: Advokatfirman Cederquist KB. 1997; 81

[38] W H Meckling. Value and the choice of the model of the individual in the social science - Swiss Journal of Economics and Statistics (SJES), - ideas.repec.org. 1976.

[39] WL Tate, LM Ellram, SW Brown. Offshore outsourcing of services: A stakeholder perspective - Journal of Servicejournals.sagepub.com. 2009.

[40] World Bank. Ghana Country Procurement Assessment Report. World Bank, Washington, D.C. 2013.

[41] World Bank. Ghana Country Procurement Assessment Report. World Bank, Washington, D.C. 2003.

[42] World Bank. "Guidelines: Procurement under IBRD Loans and IDA Credits", World Bank, Washington, D.C. 1995. 